\title{
Description and interpretation of the internal structure of a Cambrian crustacean compound eye
}

\author{
BrigitTe SChOenemann, EuAn N.K. Clarkson, Christopher Castellani, Dieter Waloszek, \\ ANDREAS MAAS \& VICTOR BENNO MEYER-ROCHOW
}

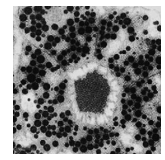

\begin{abstract}
The exceptionally good preservation of phosphatised, three dimensionally preserved "Orsten" arthropods permits insight into the internal morphology of ancient compound eyes. Analysis, presented here, of the stalked eyes of a Cambrian "Orsten" crustacean reveals structures such as a cornea, a crystalline cone, rhabdomers belonging to possibly five or six sensory cells and an absence of a gap (known as the clear-zone) between dioptric structures and the retina. All these features collectively suggest that this compound eye is of the apposition type. Thus, the principle of mosaic vision likely dates back to Cambrian times, more than half a billion years ago. Using well-established methods this eye can be characterised as dim-light adapted and is likely to have belonged to a benthic organism like many others known from fossils of the Cambrian Alum Shale of Sweden. This seems to be one of the oldest known apposition eyes, and the structural differences between it and eyes more closely conforming to the tetraconate system are likely to be related to the small size of the eye and the photic environment in which it had to operate. Differences from typical compound eye organisation, such as for instance a smaller number of retinula cells than the more typical eight found in most tetraconate arthropods, suggest that either the tetraconate system is not basal and universal, as is often assumed, or that modifications to the system enabling the eye to improve photon capture had already occurred during the Cambrian. - Key words: Tetraconata, photoreceptor, vision, Arthropoda, Cambrian, apposition eye, photic environment.
\end{abstract}

Schoenemann, B., Clarkson, E.N.K., Castellani, C., Waloszek, D., MaAs, A. \& MeYer-Rochow, V.B. 2014. Description and interpretation of the internal structure of a Cambrian crustacean compound eye. Bulletin of Geosciences 89(2), 311-324 (6 figures). Czech Geological Survey, Prague. ISSN 1214-1119. Manuscript received March 7, 2013; accepted in revised form January 21, 2014; published online March 19, 2014; issued May 19, 2014.

Brigitte Schoenemann, Institute for Biology and its Didcatics (Zoology), University of Cologne, Herbert Lewinstrasse 10, D-50931 Köln, Germany, and Steinmann Institute for Geology, Mineralogy and Palaeontology, University of Bonn, Nussallee 8, D-53115 Bonn, Germany; B.Schoenemann@uni-koeln.de•Euan N.K. Clarkson, Grant Institute, The Kings Buildings, West Mains Road, University of Edinburgh, EH93JW Edinburgh, UK; Euan.Clarkson@ed.ac.uk •Christopher Castellani, Dieter Waloszek \& Andreas Maas, Work Group Biosystematic Documentation, University of Ulm, Helmholtzstrasse 10,D-89081 Ulm, Germany; Christopher.Castellani@uni-ulm.de, Dieter.Waloszek@uni-ulm.de, Andreas.Maas@uni-ulm.de•Victor Benno Meyer-Rochow, Hachijo Island Geothermal Energy Museum, Nakanogo, Hachijojima, 100-1623 Tokyo, Japan, and University of Oulu, Department of Biology, FIN-90401 Oulu, Finland; vmr@cc.oulu.fi

The oldest arthropods are known from the early Cambrian and are about 520 million years old. One characteristic feature of extant arthropods such as crustaceans, chelicerates, myriapods and insects is the presence of a pair of compound eyes. The fossil history of such eyes remains imperfectly known despite the excellent recent reports by Lee $e t$ al. (2011) and Paterson et al. (2011), who investigated the compound eyes of specimens from the early Cambrian Emu Bay Shale, Australia. Yet, in these as well as the well-preserved fossils of the (likewise early Cambrian) Chengjiang Lagerstätte (Maotianshan Shale) only some external characteristics of the eyes are evident (Schoenemann 2005, 2006, 2007; Liu et al. 2007; Schoenemann \& Clarkson 2008, 2010, 2011a, b; Schoenemann et al. 2009).
In Cambrian arthropods of the "Orsten" type, however, which are secondarily phosphatised and three-dimensionally preserved, several kinds of compound eyes have been described (e.g. Haug et al. 2009, Castellani et al. 2012a, Parker et al. 2013).

Compound eyes are not only old in terms of time, but possibly plesiomorphic for arthropods. Waloszek et al. (2005) suggested that anterolateral, possibly compound eyes were likely to be present in the stem species of the Arthropoda s. str. (facets have not yet been found), a taxon including euarthropods, i.e. Trilobita, Chelicerata, Crustacea, Myriapoda, Hexapoda/Insecta, and a number of fossil taxa currently excluded from Euarthropoda (Maas et al. 2004, Waloszek et al. 2007). This view was confirmed by 
Paterson et al. (2011). Compound eyes exhibiting the ground pattern of the Arthropoda s. str. were most likely stalked (Waloszek et al. 2005), a condition also present today in many extant taxa (Fig. 1A, B). The sensory structures of a fossilized trilobite compound eye of Devonian origin have recently been discovered and shown to be close to the apposition type (Schoenemann \& Clarkson 2013). For the time being, however, the initial evolution of the compound eye and whether the earliest of all compound eyes were of apposition type remains obscure.

\section{Photoreceptor types}

There are two main kinds of photoreceptive organs in animals, simple eyes and compound eyes (Bitsch \& Bitsch 2005; see also Richter et al. 2010). In simple eyes a single aperture is present, through which light is directed to a retina of multiple photoreceptive cells. Eyes of this kind occur in various taxa, such as craniate Chordata, cubozoan Cnidaria, Mollusca, polychaete Annelida, and as the socalled median eyes of chelicerates, the nauplius eyes in crustaceans, and as stemmata and ocelli in insects. Among arthropods, such eyes were part of the ground pattern of Euarthropoda, but it is unclear whether they are present plesiomorphically or autapomorphically.

In contrast to simple eyes, compound eyes are made up of clusters of more or less identical optical units, the ommatidia, visible from the outside as facets. Eyes of this kind are possibly already part of the ground pattern of the Arthropoda s.s. (see above), and have been retained most significantly within Crustacea, Hexapoda/Insecta, Trilobita and the Scutigeromorpha and Diplopoda among the myriapods (Campbell 1975; Clarkson 1979; Müller et al. 2003, 2007; Clarkson et al. 2006). Also Chelicerata had basically retained compound eyes, with the extant Xiphosura (Fahrenbach 1969) as the single Recent example. Since each ommatidium surveys a different part of the surrounding environment, the resulting image has been termed "mosaic vision" because of the slight angular differences between adjacent ommatidia.

During the last few decades, several different types of compound eyes have been described (see Land \& Nilsson 2002 for review), which can be classified according to their different light-guiding abilities or the way in which the visual information is signal-processed. Two major kinds of compound eyes, structurally and functionally different from each other, have been designated apposition and superposition eyes since Exner (1891) first described them.

In the compound eye known as the apposition eye, a distal dioptric apparatus comprising cornea and crystalline cone cells focuses light on the rhabdom and its surrounding photoreceptor cells, which are known as retinula cells. The function of the crystalline cone is to guide or focus light entering through the corneal facet, so that it can stimulate the photopigments in the membranes of the rhabdom and thus trigger a cascade of biochemical events that lead to a photoelectric response; the latter is then conducted to the optical centres of the brain where further processing occurs. In the so-called apposition eye each ommatidium is shielded against neighbouring ommatidia by a curtain of accessory (= secondary) pigment cells. This makes optical coupling between neighbouring receptors almost impossible, and consequently the visual fields of the ommatidia are small and restricted to the light that enters through their own facets.

In the apposition type of compound eye a cluster of often 8 , but depending on the species sometimes more retinula cells [up to 11 and even 21 in the beetles Lucanus maculofemoratus (Motschulsky, 1861) and Aceraius grandis Kuwert, 1891, respectively: Gokan et al. 1998 and Gokan \& Meyer-Rochow 2000 or 14 as in the moth Operophthera brumata (Linnaeus, 1758): Meyer-Rochow \& Lau 2008] and sometimes fewer [four in Leptodora kindtii (Focke, 1844): Wolken \& Gallik 1965; five in amphipods: Debaisieux 1944, or the isopod Glyptonotus antarcticus Eights, 1852 for instance: Meyer-Rochow 1982] gives rise to a centrally fused rhabdom made up of the specialized fringes of microvilli (known as rhabdomeres) of the participating retinula cells. The photopigment molecules are housed in the microvillar membranes of these rhabdomers. Apposition compound eyes function by integrating information from the fields of view of individual facets into a mosaic-like image as if it consisted of pixels in a computer graphic. It has recently been shown, that the compound eyes of a tiny middle Cambrian "Orsten" crustacean were able to develop a sophisticated visual system to serve a presumably predatory lifestyle (Schoenemann et al. 2012) and a year earlier Paterson et al. (2011) demonstrated that the early Cambrian predator Anomalocaris sp. probably possessed a highly effective compound eye. The apposition type of compound eye is primarily present in diurnally active insect and crustacean species.

The superposition eye (also known as a clear-zone eye because of its diagnostic pigment-free gap between dioptric and light-perceiving structures) is characteristically developed in nocturnal species like moths (Yagi \& Koyama 1963), neuropterans and caddis-flies (Ehnbohm 1948, Nilsson 1990) as well as some carabid and scarabaeid beetles amongst the insects and in crayfishes, lobsters and shrimps amongst the crustaceans (Exner 1891, Stavenga 1989, Meyer-Rochow 2001). Some exceptions are known for both eye types: apposition eyes can also be present in, for example, certain nocturnal Hymenoptera (Menzi 1987; Frederiksen et al. 2008; Greiner et al. 2004, 2007), and superposition eyes have been described from some species of day-active moths (Yagi 1951, Horridge et al. 1972, Warrant 1999, Lau \& Meyer-Rochow 2007). 

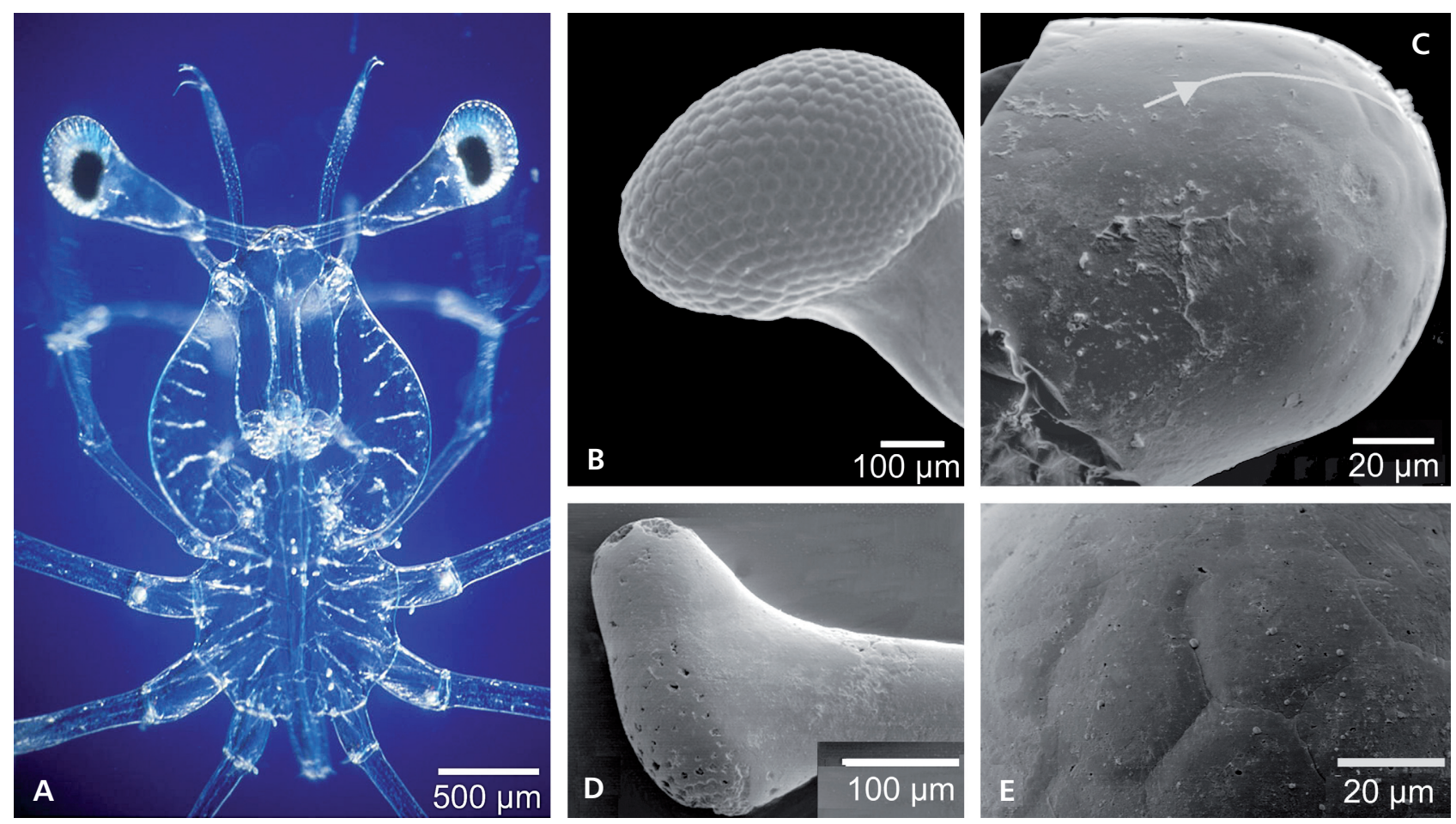

Figure 1. Comparison of the eye of a Recent phyllosoma larva and the stalked "Orsten" compound eye of a representative of the stem lineage to Eucrustacea, Henningsmoenicaris scutula (Waloszek \& Müller, 1990). • A - phyllosoma larva (second stage of development) of a rock lobster (Malacostraca: Achelata: Palinurida) with long stalked eyes. $\bullet$ B - SEM of the stalked eye of a phyllosoma larva. • C - SEM of the "Orsten" fossil eye (specimen UB W 383); arrow indicates the progression in decay and indicates the sequence of facets in Fig. 2. • D - isolated stalked eye in "Orsten"-type preservation (UB W 384). E - facetted surface (UB W 383). [Fig. 1A courtesy Image Quest Marine, Oxfordshire, UK]

The two typical features of the superposition eye include: (a) the lack of interommatidial hairs and (b) the presence of a clear-zone devoid of pigment interposed between the elements of the dioptric apparatus (i.e., cornea and cone) and the light-perceiving structures known as the retinula cells with their rhabdomeres. Other morphological features that distinguish the superposition type of eye from the apposition eye concern the screening pigment cells and pigment granule migrations during dark/light adaptation: in the superposition eye granules of the screening pigments migrate up and down the ommatidium, moving out of the clear-zone during darkness (thereby aggregating between the distal spaces of the crystalline cones and on the proximal side of the clear-zone below the rhabdoms and the tapetum if the latter is present). In the apposition eye screening pigments migrate radially away from the edge of the rhabdom in the dark and close to the edge of the rhabdom upon an exposure with bright light. This fundamental difference is the reason why the apposition eye produces an image of higher resolution than that of the superposition eye. It is because, in the latter kind of eye that is adapted to a low light intensity, incident light passing through several neighbouring facets is "shared", superpositioning it and thus ensuring that as many photons as possible reach the photoreceptors. On the other hand the discriminatory power, or acuity, is decreased relative to the appositional system, where each of the facets collects light from only a single "object-image-point".

Apposition compound eyes have been described from the small eyes of the immature stages of decapod crustacean species, in which the adults possess superposition optics and in contrast to the larvae lead nocturnal life styles and/or occur in areas with poorer light conditions than do their immature stages.

\section{Fossil compound eyes}

Although the external features of compound eyes, i.e., the facets, are frequently preserved in fossil specimens and allow valid conclusions upon their optical performance (Schoenemann \& Clarkson 2009, 2011, 2012a, b; Schoenemann et al. 2010, 2012; Lee et al. 2011; Paterson et al. 2011), internal structures are almost never available from fossil compound eyes older than about $45 \mathrm{Ma}$. The eye of a fly specimen preserved in amber from the Eocene period (Tanaka et al. 2009) permitted an unambiguous identification of the rhabdom organisation and demonstrated that it was not different from that of extant fly eyes, but amber arthropods, in general, are rather young in geological terms and, therefore, 
likely to have eyes similar to those of modern forms. Schoenemann \& Clarkson (2013) investigated the compound eyes of Devonian phacopid trilobites by $\mathrm{x}$-ray and synchrotron radiation. The authors revealed that the visual system of these trilobites was very similar to the apposition eyes of the xiphosuran Limulus polyphemus (Linnaeus, 1758).

Compound eyes, although adhering to the principle of "mosaic vision", have evolved an astonishing variety of designs especially with regard to rhabdom shapes and sizes even within a single taxon as Gokan \& Meyer-Rochow (2000) have shown for scarabaeoid beetles. In terms of morphology and physiology (e.g., spectral, absolute, and polarisation sensitivity, as well as flicker fusion frequencies, shape recognition and distance vision: Land 1981, Meyer-Rochow \& Nilsson 1999, Land \& Nilsson 2002, Warrant \& Nilsson 2006) different eye designs reflect the different environmental photic conditions that they are functioning under and the different lifestyles of their bearers. Although single-lens eyes known as ocelli in insects and as nauplius or median eyes in crustaceans, can be present in adult individuals of some species, these eyes fossilize less well and are usually much smaller than the compound eyes and thought to be involved in assessing environmental brightness, but not in image formation.

Ever since the "Orsten" fossils were first discovered, they offered new insights into Cambrian life, including the anatomy of early arthropods (e.g., Müller 1979a, b, 1983, 1985; Müller \& Waloszek 1985, 1987; Waloszek 1993, Waloszek \& Müller 1990, 1998a, b; Maas et al. 2003; Ahlberg et al. 2005; Waloszek et al. 2007; Haug et al. 2009, 2010a, b; Schoenemann et al. 2012). "Orsten" fossils, originally isolated from upper Cambrian limestone concretions collected in southern Sweden, have now been found worldwide (Maas et al. 2006). The most common "Orsten" fossils are arthropod remains; these are of small size and frequently represent larval or juvenile forms. Although "Orsten" fossils are commonly hollow because only the cuticular surface is typically preserved, the interior of the fossil can sometimes be wholly or partially filled with phosphate. Here we report upon the discovery of detached eyes belonging to, most likely, the crustacean Henningsmoenicaris scutula (Waloszek \& Müller, 1990) (Castellani et al. 2012a, Schoenemann et al. 2012). Due to the extraordinary conditions under which the "Orsten" fossils were formed, soft tissues with miniscule yet discernible structures are preserved in three dimensions. For example, it proved possible to identify the branchiopod crustacean Rehbachiella kinnekullensis as a filter feeder on account of fine setae and setulae $(<1 \mu \mathrm{m})$ present on its appendages (Waloszek 1993, 1995). The exceptional preservation of the "Orsten" fossils permits a structural interpretation of the morphological features of the eyes (for preservational aspects of this fossilization mode see Maas et al. 2006, Castellani et al. 2012b).

\section{Material and methods}

Since their first discovery in 1975 thousands of threedimensionally preserved fossil remains, mainly of small arthropods, have been found embedded in calcareous nodules, the so-called "Orsten" nodules, from the middle to late Cambrian Alum Shale succession of southern Sweden (Müller 1979, 1985; Maas et al. 2006; see Parker et al. 2013 for a cuticle fragment of a compound eye). These tiny arthropods, up to slightly more than a millimeter in size, are interpreted as inhabitants of meiobenthic life communities.

Among these, six isolated pieces of stalked compound eyes were found at a single locality in a quarry near the farm Gum, located at Mount Kinnekulle, Västergötland, and all have a similar morphology (see Castellani et al. 2012a for a morphological description of the isolated eyes and a discussion of their affinity). The material is dated to the Agnostus pisiformis Biozone (formerly representing the lowermost Zone 1 of the upper Cambrian, and recently reconsidered as the uppermost Zone of Cambrian Series 3; cf. Peng et al. 2004, Ahlberg 2003, Terfelt et al. 2008). Amongst the set of six isolated stalked eyes, two of them seem to represent later ontogenetic stages - based on the larger size and higher number of facets - than the other four. Among this sample, the two larger forms are macelike, with a long stalk continuing into the compound eye, which is characterized by a highly differentiated visual surface (Fig. 1C-E). The homogenous array of large facets is best preserved in an ontogenetically earlier form exhibiting less morphological differentiation than facets belonging to eyes, which are more advanced and show considerable regional differences across the eye. The specimens display transient variations in surface structure from the anterior to the posterior, probably the result of spreading decay, possibly caused by microbes although the exact process that could have caused the decay remains obscure (Figs 2, 3).

The specimens were dissolved from concretions by processing with acetic acid (as described by Müller 1985). The material was prepared in the early 1980s, mounted on SEM stubs and photographed in Bonn at the Palaeontological Institute, today the Steinmann Institute for Geology, Mineralogy and Palaeontology of the University of Bonn by the workgroup of the late Professor Klaus J. Müller. Specimens were re-photographed in standardised views by CC using scanning electron microscopy (SEM) at the Central Unit for Electron Microscopy at the University of Ulm, Germany, and detailed views were worked out by BS and CC in January 2010 in Ulm. Although the stalked eyes were not attached to any arthropod body, it is likely that they belong to the crustacean Henningsmoenicaris scutula, since the latter occurs in the same samples and is the only crustacean with stalked eyes in this community. The specimens, on which the main results reported in 

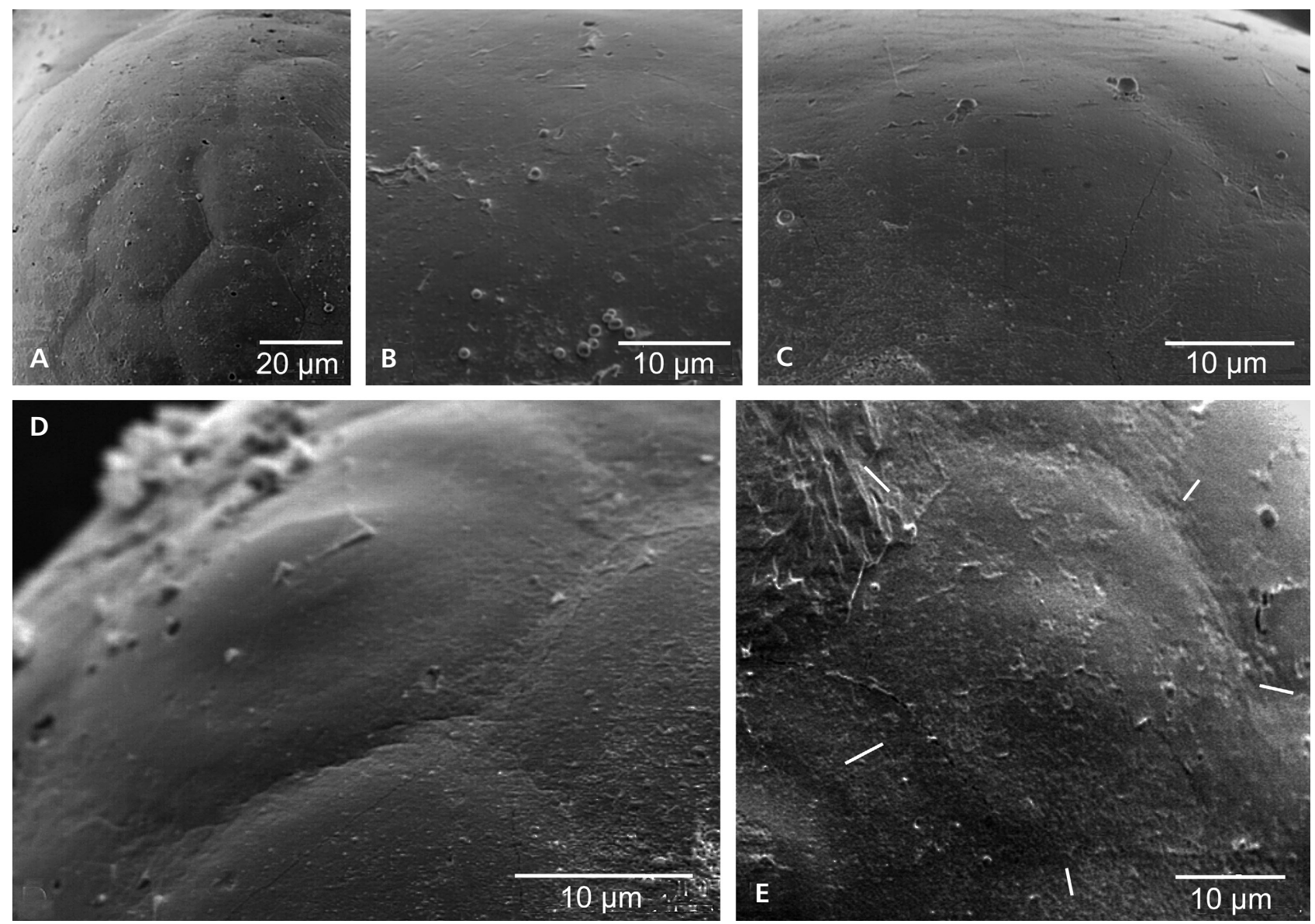

Figure 2. Facets of the stalked eye of Henningsmoenicaris scutula (Waloszek \& Müller, 1990). Facets in different areas of the stalked eye UB W 384 , differently expressed by the progress of decay, following the grey line in Fig. 1C. $\bullet$ A - overview over the frontal area showing the hexagonal pattern. - B - smooth surface, like the original visual surface. $\bullet \mathrm{C}$ - facetted surface, with smooth surface of each facet. $\bullet \mathrm{D}$ - facetted surface with a slight central dome $(\sim 16 \mu \mathrm{m}$ in diameter), surrounded by a wider ring (width of the ring $\sim 7 \mu \mathrm{m}$ it inner diameter $\sim 24 \mu \mathrm{m}$ ). $\bullet \mathrm{E}$ - five-fold structure of the ommatidium, the position of the boundaries between the individual cells is indicated by white lines.

this paper are based, form part of the collection of the Steinmann Institute of Geology, Mineralogy and Palaeontology, University of Bonn (but are currently housed at the University of Ulm); repository numbers UB W 383, UB W 384.

\section{Analysis of the eyes}

On the visual surface four areas can be distinguished, in which the structures appear in different states of preservation (cf. Fig. 2A-E). These are gradual, with a continuous transition between the end members:

A. A smooth surface where the outlines and borders of facets are not clearly visible (Fig. 2B);

B. A smooth facet surface, but with the facet borders visible (Fig. 2A, C);

C. An area with regularly arranged, slightly dome-shaped facets, approximately $18 \mu \mathrm{m}$ high in the centre, separated from neighbouring facets by a space $c a 6 \mu \mathrm{m}$ wide (Fig. 2D). The diameter of a whole entire facet, gaps between facets not included, is $c a 28 \mu \mathrm{m}$.

D. Facets with a central dome surrounded by possibly five polygonal (three- to five-sided) structures (Fig. 2E).

This sequence, if accepted, becomes readily understandable and can be interpreted as a result of gradual decay of the soft internal structures of the eye, which proceeded from distal to proximal, i.e., surface to inner layers (Fig. 3). Assuming that this interpretation is correct, the smooth surface (Fig. 2A) shows the original (non-decayed) visual surface, as can be observed in modern crustaceans, e.g., the phyllosoma larva of a rock lobster (Fig. 1A, B), the adult branchiopod Artemia salina Linnaeus, 1758 (Elofsson 1976, Hallberg et al. 1980), and the amphipod Dulichia porrecta (Bate, 1857) (Meyer-Rochow et al. 1991). Even the stalks of extant species bearing compound eyes resemble those of the fossil eyes (Fig. 1B, D).

The first stages of decay are likely to have caused shrinkage, which allowed impressions of the underlying structures on the thin corneal surface. Stages A and B (see above; 
Fig. 2A, B) most likely represent the original or slightly decayed visual surface, respectively, but no underlying structures are discernible. In stage C (Fig. 2D), the integrity of the corneal cover has changed: a smooth and slightly elevated dome has developed in the centre, which may represent the tip of the underlying crystalline cone seen through the collapsed corneal cover. By comparison with isopod and amphipod eyes (see Fig. 3), the apparent ring that appears to surround the cone in the "Orsten" fossil (Fig. 2D) may consist of two corneagenous cells, two smaller crystalline cone cells and the distal extensions of a variable number of accessory pigment cells peripheral to the cone. In Malacostraca between two and six such cells, depending on the species, can be assigned to each ommatidium. Details of these cells and borders between them cannot be discerned through the overlying corneal cuticle of the fossil eye.

The crystalline cone of the fossil eye, in contrast to that of insects and most decapod crustaceans, appears globular, rather than conical and resembles that of the benthic Antarctic isopods and amphipods (Meyer-Rochow 1981, 1982). If this structure, consisting of primarily just two large cells, had burst during the process of decay, the velum of the crystalline cone would be flattened and changed into a circular sheet, leaving no visible traces under the thin cuticle. Instead, a more differentiated pattern has resulted, consisting of possibly five polygons (three- to five-sided) (Fig. 2E), arranged around a central cupola. Again, with reference to the structure of the marine isopods and amphipods mentioned earlier ( $c f$. Fig. 3), the shapes of the retinula cells create a sculptured surface through their impressions on the overlying corneal sheets. Consequently, the central dome might be interpreted as a relict of the original light-guiding rhabdom.

Under the corneal cover, the outlines of probably no more than five narrowly separated cells are visible (Figs 2E, 3C, 4A). These are interpreted as retinula cells, because they correspond in position and number to the eyes of amphipod malacostracans, such as species of Orchomene Boeck, 1871 and Dulichia Krøyer, 1845 (MeyerRochow et al. 1991) or isopod species, such as of the taxa Glyptonotus Eights, 1852 or Saduria Adams, 1852 (Meyer-Rochow 1982, Lindström et al. 1991), or the anostracan branchiopod Artemia salina (Hallberg et al. 1980) (Figs 4D, 5, 6).

\section{Discussion}

\section{Similarities to other compound eyes}

The presence of an eyestalk, and a compound eye exhibiting hexagonally-shaped facets in the "Orsten" fossil eye presented herein are interpreted as being plesiomorphic features retained from, at least, the ground pattern of the
Euarthropoda, possibly even down to Arthropoda s.s. The similarity of the cell outlines to cell arrangements of our fossil material with that of Recent compound eyes is striking, especially when considering the eyes of some isopods and amphipods, for which excellent morphological analyses exist (e.g., Meyer-Rochow \& Tiang 1979; Mayrat 1981; Meyer-Rochow 1982, 1985; Chamberlain et al. 1986; Hariyama et al. 1986; Rosenberg \& Langer 1995; Keskinen et al. 2002). Also the facet diameter of $\mathrm{ca} 28 \mu \mathrm{m}$ in our "Orsten" fossil is rather close to that of the pelagic phyllosoma larva of the rock lobster Jasus edwardsii (Hutton, 1875), which is $24 \mu \mathrm{m}$.

Whether abrasion or a proximally advancing decay, caused by micro-organisms, was responsible for exposing ommatidial structures normally covered and hidden by the cornea cannot be decided, but in contrast to the compound eyes of terrestrial arthropods, typical aquatic compound eyes usually do not possess a cuticular lens and the cornea is usually membranous. The "Orsten" eye has a smooth surface at stage A (Fig. 2B), which is comparable to that of many extant forms of crustacean compound eyes and indicates the original nature of the surface. Features shown best in Fig. 2B suggest that the covering corneal cuticle has been rather thin and membranous, as is the case of most aquatic arthropods even today (Thiele 1971).

Because of the small difference in refractive indices between seawater and organic material, the corneal cuticle of aquatic arthropods represents a far less powerful refracting quality than that of compound eyes of terrestrial arthropods, some of which have very effective corneal lenses (Meggitt \& Meyer-Rochow 1975). The function of focusing the incident light on the receptor, or at least "channelling" it to the interior of the ommatidium, in aquatic compound eyes is usually achieved by the crystalline cone.

\section{The retinal organisation}

Stalked eyes with smooth outer surfaces are very common among decapod crustaceans and their pelagic larvae. Yet, irrespective of this feature the internal structure below the cornea may belong to either an apposition or superposition type of eye (Land 1984). An interesting case is that of larval rock lobsters (Achelata, Decapoda, Malacostraca). The eye of such phyllosoma larvae, occupying the distal end of a long eye stalk, has an appearance and shape that closely resembles that of the fossilised eyes described in this paper (cf. fig. 1A, B, D in Mishra et al. 2006). It has an apposition eye (Mishra et al. 2006), but these changes into a reflecting superposition eye with square facets when the larva abandons its planktonic lifestyle and moves to the sea bottom (Meyer-Rochow 1975; see Haug \& Haug 2013 for a recent overview of fossil achelatan larvae and the ontogeny of achelatan species). 


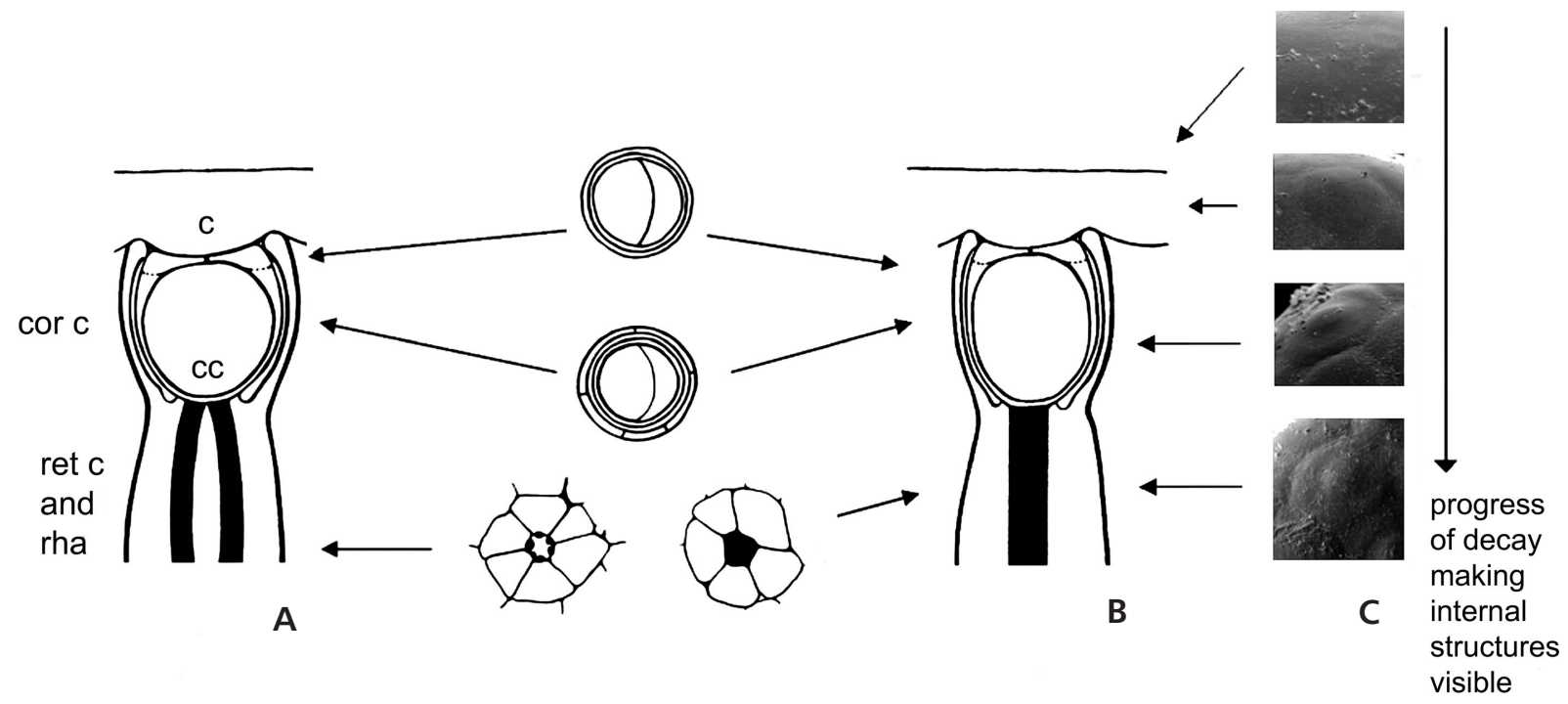

Figure 3. Comparison of the internal structures of facets of the stalked eye of the Recent marine isopod Ligia exotica Roux, 1828 and Henningsmoenicaris scutula (Waloszek \& Müller, 1990). • A - schematic drawing of the inner ommatidial structure of Ligia exotica (after Hariyama et al. 1986). B - schematic drawing of the amphipod Orchomene plebs (Hurley, 1965) (after Meyer-Rochow \& Tiang 1979), similar to the "Orsten" crustacean ommatidium (C). Abbreviations: c - cuticule; cor c - corneagenous cells; cc - crystalline cone; $\mathrm{c}$ - retinula cells; rha - rhabdom.

Figure 4. Comparison of retinular structures. $\bullet$ A - Henningsmoenicaris scutula (Waloszek \& Müller, 1990) with 5 retinula cells. • B - Dulichia (amphipod) with 5 retinula cells. $\bullet \mathrm{C}-$ Ligia exotica Roux, 1828 (isopod) with 6 retinula cells. $\cdot \mathrm{D}-$ phyllosoma larva of a rock lobster (Decapoda) with 7 retinula cells.
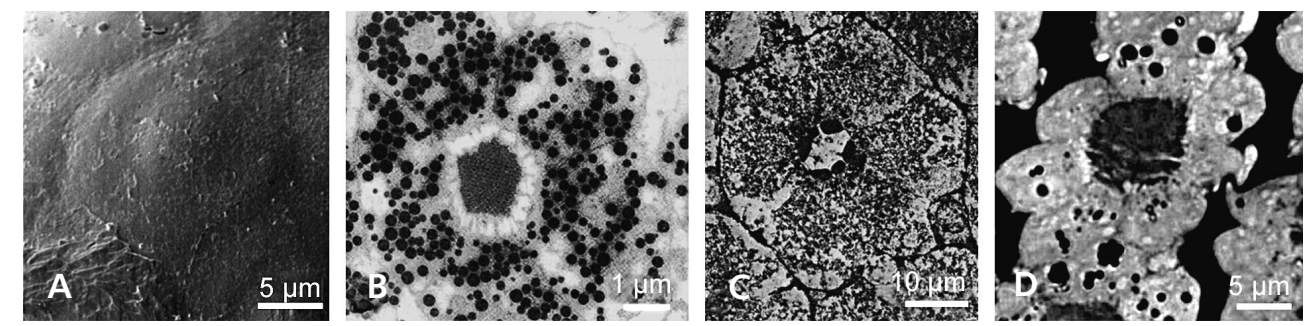

The number of retinula cells per ommatidium is not affected by the change to the more specialised superposition type, but rhabdom outlines are (Meyer-Rochow 1975, Mishra et al. 2006). Additional cases have been described in which apposition eyes ontogenetically precede those with superposition optics (Meyer-Rochow 1975, Fincham 1984, Nilsson et al. 1986, Mishra et al. 2006), but they are all restricted to decapod crustaceans. Peracarida like isopods and amphipods never possess superposition eyes, but exhibit a variety of apposition eye adaptations matching lifestyle and photic environment. Since the number of the retinula cells per ommatidium does not change with age, this character can be considered to be more reliable than whether an eye corresponds to apposition or superposition type.

One further aspect to be considered relates to the question of whether ommatidial rhabdoms were fused and formed a centrally placed column-like structure surrounded by their retinula cells or whether neighbouring rhabdomeres were not connected and, thus, gave rise to an open rhabdom. Our fossil eye's similarity to that of the eyes of amphipods and isopods suggests that it was fused, a situation that is, generally speaking, vastly more common in crustaceans than an open system, which in crustaceans is known so far only from the highly regressed eye of the cave shrimp (atyid decapod) Typhlatya garciai (Meyer-Rochow \& Juberthie-Jupeau 1983) and the eye of the semi-terrestrial isopod Ligia exotica (Hariyama et al. 1986). Characteristic for insects of the order Diptera, the open rhabdom condition has been shown to be advantageous in the detection of movement (Srinivasan \& Guy 1990), a need that for aquatic arthropods is much less acute.

Regarding the "Orsten" material we have to discuss two seemingly discordant findings: the presence of an eyestalk and an apposition eye with apparently only 5 or 6 retinula cells. The small number of receptor cells seems to be genuine and maintained throughout the length of the ommatidium. Tiered retinas, common in insects (e.g., Thysanura: Paulus 1979; dragonflies: Ninomiya et al. 1969; crickets: Wachmann 1970; and Plecoptera: Nagashima \& Meyer-Rochow 1995 and also described from the eye of the chilopod Scutigera coleoptrata by Müller et al. 2003) are virtually unknown in crustaceans. Although in some species a distal rhabdom may be developed by one cell alone [e.g., in the crabs of the taxon Grapsus Lamarck, 
1801: Eguchi \& Waterman 1973 and in the rock lobster Panulirus longipes (A. Milne Edwards, 1868): MeyerRochow 1975], retinula cells are usually present from the most distal to the most proximal reaches of the retina. The same holds true for isopods and amphipods, in which 4-5, rarely 6 , retinula cells are present throughout the retinal extent. Thus, a tiered arrangement of retinula cells with several distal ones above several proximal ones can almost certainly be ruled out in our "Orsten" fossil.

\section{The ancestral pattern}

The presence of four crystalline cone cells, eight retinula cells, and a variable number of accessory pigment cells (Fig. 4A-D) was thought to be the ancestral pattern for the taxon Tetraconata (i.e., Crustacea + Hexapoda: Dohle 1998, Richter 2002, Richter et al. 2010). Since Müller et al. (2003, 2007) and Harzsch et al. (2007) were able to find the same pattern in myriapods it has frequently been referred to as the "ground pattern" of the so-called mandibulate (combination of Crustacea, Insecta, Myriapoda) Euarthropoda. Since Oakley (2003) showed that cell numbers exhibit wide variations amongst the various arthropod ommatidia, it is, therefore, uncertain whether four cone cells and eight retinula cells can indeed be considered the ground pattern condition at least for mandibulate Euarthropoda. However, the observations made by Oakley (2003) could also be explained as autapomorphic changes from a common "tetraconate" situation. Among Branchiopoda the Anostraca have crystalline cones formed by four cone cells, but they have five, or maximally six, retinula cells (Elofsson \& Odselius 1975). In amphipods five retinula cells are the rule and in isopods five, six or more have been reported, but their cones consist of only two large cells (Nemanic 1975, Meyer-Rochow 1982, Ax 1999). The highly specialised predatory cladoceran Leptodora kindtii has cones made up of 5 cells and ommatidial clusters of only 4 retinula cells (Wolken \& Gallik 1965).

As mentioned above, Recent isopods and amphipods possess sessile eyes, but motile stalked eyes - as in lophogastrids, mysids or mictaceans - are regarded as the ancestral and sessile eyes (and absence of eyes) as derived condition (Brusca \& Wilson 1991). Morover, Mysida, unlike Isopoda and Amphipoda, have stalked eyes that possess a clear-zone when the animals are adult (Hallberg 1977, Gaten et al. 2002). Larvae of crustaceans in which the adults feature a distinct clear-zone often lack this structure and resemble apposition eyes (Panulirus longipes: Meyer-Rochow 1975; Palaemon serratus: Fincham 1984; Neomysis integer and Thysanoessa raschii: Nilsson et al. 1986; Jasus edwardsii: Mishra et al. 2006). The "Orsten" material could therefore have belonged to an immature individual not yet endowed with an obvious clear-zone.
One other possible explanation for the absence of a clear-zone is that because of its fragile nature and lack of stabilizing anatomical elements in it, the clear-zone could simply have collapsed before fossilisation. That clearzones can indeed collapse was shown by Nilsson (1990) for three species of extant deep sea crustaceans, but it has never been demonstrated in fossil material.

\section{Photic environment and sensitivity}

There exist effective mechanisms to enhance the sensitivity of very small compound eyes by adapting the functional morphology of the rhabdomers, as has been described by Paulus (1979) and Fischer et al. (2011, 2012). Irrespective of whether or not eight cells represent the plesiomorphic condition early in the Cambrian the probably smaller number of receptor cells seen in our material and in the generally more benthic rather than pelagic recent isopods and amphipods requires an explanation. If eight sensory cells contribute to the formation of the rhabdom, under lower light conditions the amount of available photons to each one of them may not be high enough to generate a conductible electrical signal, but with only 5 retinula cells (i.e., $20 \%$ of the light entering the rhabdom versus $12.5 \%$ in rhabdoms composed by 8 cells) the share of photons each one receives is increased and may be sufficient to generate a conductible response. This calculation is based on the fact that aquatic isopods and amphipods (but not necessarily their semi-terrestrial relatives) appear to have but one spectral sensitivity peak (Donner 1971, Meyer-Rochow \& Laughlin 1997); thus making it unlikely that spectrally different cells contribute to the bulk of the rhabdom.

The original number of sensory cells per ommatidium may have evolutionarily been reduced in combination with an enlargement of the rhabdom diameter as demonstrated by Hallberg et al. (1980) for the deep-sea amphipods Eurythenes gryllus $(40 \mu \mathrm{m})$ and Orchomenopsis obtusa $(20-40 \mu \mathrm{m})$ or by Meyer-Rochow (1981) for the benthic Orchomene sp. cf. O. rossi (approx. 40-50 $\mu \mathrm{m}$ ). The lifestyle of an animal and the photic environment it occurs in are frequently mirrored by the kind of eye the animal has. Constantly low ambient light conditions necessitate wider apertures through which light can enter the eye - and correlates with larger rhabdoms. The more pixels the image consists of, the higher the resolution, but unfortunately smaller facet "windows" permit less light to enter and excite the photosensitive membranes further below and, therefore, lead to reduced visual sensitivity. However, resolution means nothing if the eye is not sufficiently sensitive to light. Thus, to perceive intensity differences of light has to be given priority. Therefore, five retinula cells could possibly be a functional adaptation to low light conditions. 

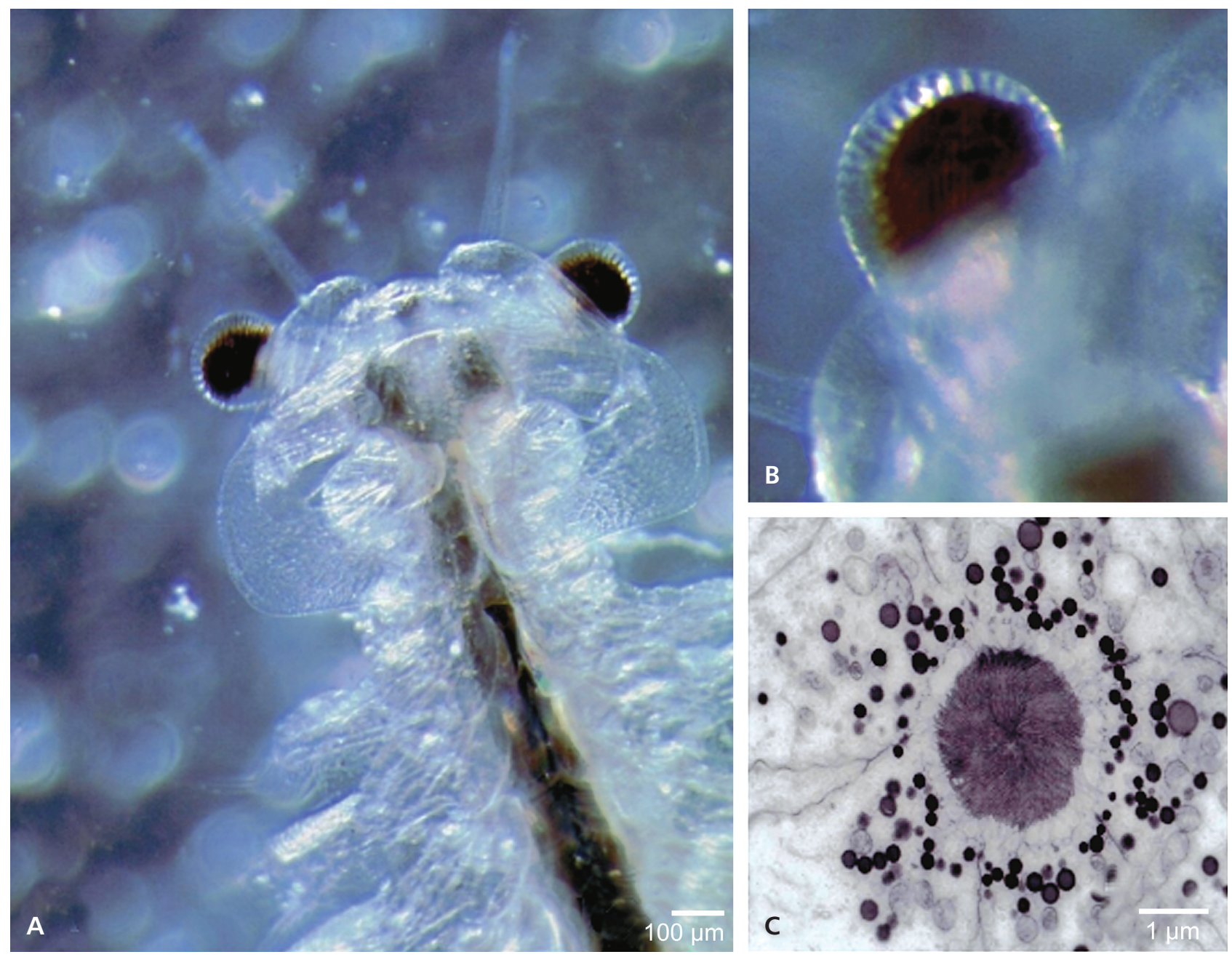

Figure 5. Details of the Recent branchiopod Artemia salina (Linnaeus, 1758) and the amphipod Dyopedos porrectus Bate, 1857. $\bullet$ A - head of $A$. salina. - B - left eye of A. salina, showing singular visual units and a smooth surface of the eye. C-histological cross section of an ommatidium of. D. porrectus. Five sensory cells and a cetrally fused rhabdom can be seen.

Since the late 1970s, excellent tools for estimating the light sensitivity of compound eyes based on their outer morphology alone have been established. These tools also allow assignment of such eyes to specific ecological habitats and to reconstruct associated light conditions to which they were adapted (Snyder 1977, 1979; Snyder et al. 1977; Horridge 1977; Land 1981). This is made possible by measuring the diameters of the lenses and the opening angle of the facet (or the angle of divergence of the ommatidia). These measurements are also possible on fossils with well preserved compound eyes, and have been used as a standard method since 1989 by a variety of researchers (Fordyce \& Cronin 1989; McCormick \& Fortey 1998; Lee et al. 2011; Paterson et al. 2011; Schoenemann \& Clarkson 2010, 2011a, b; Schoenemann et al. 2010, 2011). The principle is simple and based on the fact that the resolution of a compound eye is dependent on the number of facets present, the angle between them, and the acceptance angle of the receptor cells. The amount of light a single facet can capture, however, depends on the diameter of the facet and the optical properties of the dioptric structures (refractive indices and lens cylinder features). The compromise between small, numerous lenses and a facet diameter working at threshold conditions is described by the so-called eye parameter (see Snyder 1977, 1979; Snyder et al. 1977; Horridge 1977).

This trade-off leads to a compromise and allows the determination of the value of " $p$ ", the eye parameter, defined as: $p=D \cdot \Delta \varphi$ [ $\mu \mathrm{m} \mathrm{rad}]$ (Snyder 1977, 1979; Snyder et al. 1977; Horridge 1977). Since the eye parameter depends on the lens diameter $\mathrm{D}[\mu \mathrm{m}]$ and the interommatidial angle $\Delta \varphi$ [rad]. The latter should be as small as possible to achieve the greatest resolution, i.e., a small $p$ value, conversely, a large $p$ value means dark-adapted eyes. Many investigations, involving both extant and fossil arthropods, have demonstrated the practicality of the eye parameter for assigning 


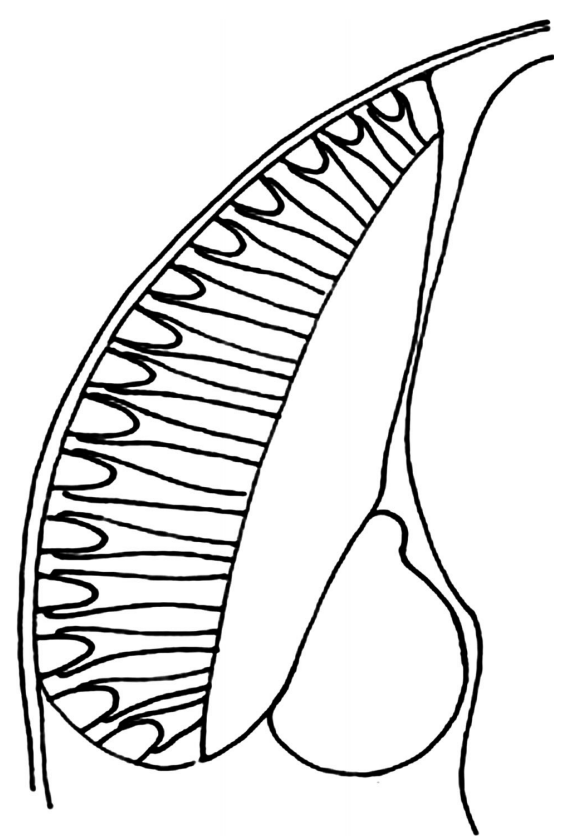

Figure 6. Schematic drawing of the eye of Artemia salina (after Hallberg et al. 1980).

recent systems to their habitat (for an overview, see Land 1981) that even fossil eyes could be studied with respect to questions concerning palaeoecological environments was shown by Land (1981), Fordyce \& Cronin (1989) and McCormick \& Fortey (1998).

Given this background information on compound eye parameters, we can estimate the parameter of the fossil eye as $p=19.5 \mu \mathrm{m} \cdot \operatorname{rad}[p=(1 / 2 \sqrt{ } 3) \cdot D \cdot \Delta \varphi$, hexagonal pattern of the facets, $\mathrm{D} \sim 28 \mu \mathrm{m}]$, which suggests adaptation to rather low light conditions. This conforms to an estimation of the absolute sensitivity of $S=0.62 \cdot D^{2} \cdot \Delta \rho^{2} \cdot P_{\mathrm{abs}}\left[\mu \mathrm{m}^{2} \mathrm{sr}\right]$ (Land 1981, Frederiksen \& Warrant 2008). [The factor 0.62 is $(\pi / 4)^{2}$, because all structures involved are spherical, $P_{\mathrm{abs}}$ is a factor describing how much of the incident light is absorbed by the rhabdom, and lies between 0.1 and 0.9 (Land 1981, Land \& Nilsson 2002).] The anatomically-derived sensitivity of the eye investigated here lies between $78\left[\mu^{2} \mathrm{sr}\right]\left(P_{\mathrm{abs}}=0.1\right)$ and $709\left[\mu \mathrm{m}^{2} \mathrm{sr}\right]\left(P_{\mathrm{abs}}=0.9\right)$, which indicates a low-light adapted visual system similar to that seen in the coastal, mainly nocturnal horseshoe crab Limulus $\left(S=83-317\left[\mu \mathrm{m}^{2} \mathrm{sr}\right]\right.$ ) (Land \& Nilsson 2002; for further details on the optimal relation $\Delta \rho / \Delta \varphi<0.75$ see Snyder 1977, p. 174).

Because the fossil eye as a whole is rather small and the lenses are comparably large the acuity of the eye has to be poor. The spatial frequency $v_{s}=1.46 \mathrm{cycles} / \mathrm{rad}$, a measure of the fineness of scanning $\left[1 /(\sqrt{ } 3 \cdot \Delta \varphi)=v_{s}\right.$ in hexagonally patterned facets (Snyder 1977)], is relatively low and lies close to that of the deep sea isopod Cirolana borealis $\left(v_{s}=1.90\right.$ cycles/rad) (Land \& Nilsson 2002, based on measurements by Lindström \& Nilsson 1983), which has an ap- position eye that sacrifices acuity in order to gather more light with the aid of a massive rhabdom.

\section{The "Orsten" fossil eye}

Many "Orsten" fossils represent mainly larval or smallsized forms of arthropods, which lived on or close to the sea floor, possibly some also slightly within the upper layer (flocculent zone, see Müller \& Waloszek 1991) up to depths of $200 \mathrm{~m}$ in murky water and dim light conditions (Waloszek 1993). Hence, we can expect this be the environment to which the eye of our fossil was adapted. The enigma of this eye and its anatomy may be solved by considering that the eye diameter, based on the part of the eye investigated, does not appear to be larger than $60 \mu \mathrm{m}$. Thus the length of a rhabdom cannot be much more than $30 \mu \mathrm{m}$, because of the limited space in this small eye. As light inside a rhabdom is absorbed exponentially and the coefficient of absorbance - the rate of absorbance by the "rhabdom material" - is known for different arthropods, Land estimated that the length of a rhabdom absorbing $80 \%$ of the incident light should be about $240 \mu \mathrm{m}$ long (Land 1981). The short length of the rhabdom in the tiny "Orsten" eye might be compensated for to some extent by the relatively large lenses ( $28 \mu \mathrm{m}$ in diameter) and also the comparatively large rhabdom diameter $(\sim 18 \mu \mathrm{m}$, Fig. $2 \mathrm{C} ; \sim 20 \mu \mathrm{m}$, Fig 2D).

Wider lenses of comparable size are known from other small fossil arthropods as well, such as the tiny planktonic trilobite Ctenopyge ceciliae Clarkson \& Ahlberg, 2002 (Schoenemann et al. 2008, 2010). Among Recent amphipods the diameters of rhabdoms vary from $2.7 \mu \mathrm{m}$ in male Dyopedos porrectus Bate, 1857 (= Dulichia porrecta; Meyer Rochow et al. 1991) to more than $30 \mu \mathrm{m}$ in deep water species (Hallberg et al. 1980, Meyer-Rochow 1981), and it is evident that rhabdoms in crustaceans generally, and amphipods and isopods in particular, increase in width with the depth, at which the species lives (Meyer-Rochow \& Nilsson 1999). It follows that our fossil species would not have been a shallow water species.

\section{Conclusions}

The short distance between the distal end of the rhabdom and the surface layers of the eye suggests that the "Orsten" crustacean had an apposition type of eye and not the more specialised superposition eye, in which the distance from dioptric apparatus to rhabdom is typically much larger. The eyes of the "Orsten" crustacean described in this paper, thus, may be among the oldest apposition eyes reported so far. The eyes appear to exhibit adaptations to have functioned in a dim light environment. 


\section{Acknowledgements}

We are greatly indebted to two anonymous reviewers and assistant editor N. Hughes for their helpful hints, which helped us to improve our paper.

\section{References}

ANDRES, D. 1989. Phosphatisierte Fossilien aus dem unteren Ordoviz von Südschweden. Berliner geowissenschaftliche Abhandlungen A 106, 9-19.

Ahlberg, P. 2003. Trilobites and international tie points in the Upper Cambrian of Scandinavia. Geologica Acta 1, 127-134.

Ahlberg, P., Szaniawski, H., Clarkson, E.N.K. \& Bengtson, S. 2005. Phosphatised olenid trilobites and associated fauna from the Upper Cambrian of Västergötland, Sweden. Acta Palaeontologica Polonica 50(3), 429-440.

Ax, P. 1999. Das System der Metazoa II. 384 pp. Gustav Fischer, Stuttgart, Jena, Lübeck, Ulm.

BAte, C.S. 1857. A synopsis of the British edriophthalmous Crustacea. Annals and Magazine of Natural History, Series 2 19, 135-152.

Bitsch, C. \& Bitsch, J. 2005. Evolution of eye structure and arthropod phylogeny. Crustacean Issues 16, 185-214.

DOI 10.1201/9781420037548.ch8

BRUSCA, R.C. \& WILSON, G.D.F. 1991. A phylogenetic analysis of the isopoda with some classificatory recommendations. Memoirs of the Queensland Museum 31, 143-204.

Campbell, K.S.W. 1975. The functional anatomy of phacopid trilobites: musculature and eyes. Journal and Proceedings of the Royal Society of New South Wales 108, 168-188.

Castellani, C., Haug, J.T., Haug, C., Maas, A., Schoenemann, B. \& WALOSZEK, D. 2012. Exceptionally well-preserved isolated eyes from late Cambrian 'Orsten' faunal assemblages of Sweden. Palaeontology 55(3), 553-566. DOI 10.1111/j.1475-4983.2012.01153.x

Chamberlain, S.C., Meyer-Rochow, V.B., William, P. \& DosSERT, W.P. 1986. Morphology of the compound eye of the giant deep sea isopod Bathynomus giganteus. Journal of Morphology 189(2), 145-156. DOI 10.1002/jmor.1051890205

Clarkson, E.N.K. 1979. The visual system of trilobites. Palaeontology 22, 1-22.

Clarkson, E.N.K., Levi-Setti, R. \& Horvath, G. 2006. The eyes of trilobites; the oldest preserved visual system. Arthropod Structure and Development 35, 247-259. DOI 10.1016/j.asd.2006.08.002

Debaisieux, P. 1944. Les yeux des crustacés - structure, développement, réactions à l'éclairement. Cellule 50, 9-122.

DoHLE, W. 1998. Myriapod-insect relationships as opposed to an insect-crustacean sister group relationship, 305-315. In Fortey, R.A. \& THOMAs, R.H. (eds) Arthropod Relationships. Systematics Association, Special Volume Series 55. Chapman \& Hall, London.

Donner, K.O. 1971. On vision in Pontoporeia affinis and $P$. femorata (Crustacea, Amphipoda). Commentationes biologiae 41, 1-17.

Eguchi, E. \& Waterman, T.H. 1965. Fine structure patterns in crustacean rhabdoms, 105-124. In Bernhard, C.G. (ed.) Functional organization of the compound eye. Pergamon Press, Oxford.

Eнnвонм, K. 1948. Studies on the central and sympathetic nervous system and some sense organs in the head of neuropteroid insects. Opuscula Enthomologica Supplementum 8, $1-162$.

ElofsSon, R. 1976. Rhabdom adaptation and its phylogenetic significance. Zoologica Scripta 5, 97-101. DOI 10.1111/j.1463-6409.1976.tb00685.x

ElofsSon, R. \& OdSELIUS, R. 1975. The anostracan rhabdom and the basement membrane. An ultrastructural study of the Artemia compound eye (Crustacea). Acta Zoologica Stockholm 56, 141-153. DOI 10.1111/j.1463-6395.1975.tb00089.x

Exner, S. 1891. Die Physiologie der facettirten Augen von Krebsen und Insecten. 206 pp. Franz Deuticke Verlag, Leipzig \& Wien. DOI 10.5962/bhl.title.2149

FAHRENBACH, W.H. 1969. The morphology of the eyes of Limulus. II. Ommatidia of the compound eye. Zeitschrift für Zellforschung 93, 451-483. DOI 10.1007/BF00338531

Fincham, A.A. 1984. Ontogeny and optics of the eyes of common prawn Palaemon serratus (Pennant, 1777). Zoological Journal of the Linnean Society 81, 89-113. DOI 10.1111/j.1096-3642.1984.tb01173.x

Fischer, S., Müller, C. \& Meyer-Rochow, V.B. 2011. How small can small be: The compound eye of the parasitoid wasp Trichogramma evanescens (Westwood, 1833) (Hymenoptera, Hexapoda), an insect of 0.3-0.4 mm total body size. Visual Neuroscience 28, 295-308.

DOI $10.1017 /$ S0952523810000192

Fischer, S., Meyer-Rochow, V.B. \& Müller, C. 2012. Challenging limits: ultrastructure and size-related functional constraints of the compound eye of Stigmella microtheriella (Lepidoptera: Nepticulidae). Journal of Morphology 273, 1064-1078. DOI 10.1002/jmor.20045

FREDERIKSEN, R. \& WARRANT, E.J. 2008. The optical sensitivity of compound eyes: theory and experiment compared. Biology Letters 4(6), 745-747. DOI 10.1098/rsbl.2008.0467

Fordyce, D. \& Cronin, T.W. 1989. Comparison of fossilized schizochroal compound eyes of phacopid trilobites with eyes of modern marine crustaceans and other arthropods. Journal of Crustacean Biology 9, 554-569. DOI 10.2307/1548587

García-Bellido, D.C. \& Collins, D. 2007. Reassessment of the genus Leanchoilia (Arthropoda, Arachnomorpha) from the Middle Cambrian Burgess Shale, British Columbia, Canada. Palaeontology 50(3), 693-709.

DOI 10.1111/j.1475-4983.2007.00649.x

Gaten, E., Herring, P.J. \& Shelton, P.M.J. 2002. Eye morphology and optics of a double-eyed mysid shrimp, Euchaetomera typical. Acta Zoologica 83, 221-230.

DOI 10.1046/j.1463-6395.2002.00116.x

GoKan, H. \& Meyer-Rochow, V.B. 2000. Morphological comparisons of compound eyes in Scarabaeoidea (Coleoptera) related to the beetles' daily activity maxima and phylogenetic positions. Journal of Agricultural Science 45(1), 15-61.

Gokan, H., Meyer-Rochow, V.B., Nakazawa, A. \& Iida, K. 1998. Compound eye ultrastructures in six species of ecologically diverse stag beetles (Coleoptera, Scarabaeoidea, Lucanidae). Applied Entomology and Zoology 33, 157-169. 
Greiner, B., Cronin, T.W., Ribi, W.A., Wcislo, W.T. \& WarRANT, E. 2007. Anatomical and physiological evindence for polarization vision in the nocturnal bee Megalopter genalis. Journal of Comparative Physiology A 193(6), 591-600. DOI 10.1007/s00359-007-0214-1

Greiner, B., Ribi, W.A. \& WarRANT, E. 2004. Retinal and optical adaptations for nocturnal vision in the adaptations for nocturnal vision in the halictid bee Megalopta genalis. Cell and Tissue Research 316(3), 377-390.

DOI 10.1007/s00441-004-0883-9

HALLBERG, E. 1977. The fine structure of the compound eyes of mysids (Crustacea: Mysidacea). Cell and Tissue Research 184, 45-65. DOI 10.1007/BF00220526

HallberG, E., Nilsson, D.E. \& Elofsson, R. 1980. Classification of amphipod compound eyes - the fine structure of ommatidial units (Crustacea, Amphipoda). Zoomorphologie 94, 279-306. DOI 10.1007/BF00998206

Hariyama, T., Meyer-Rochow, B.V. \& Eguchi, E. 1986. Diurnal changes in structure and function of the compound eye of Ligia exotica. Journal of Experimental Biology 123, 1-26.

Harzsch, S., Melzer, R.R. \& Müller, C.H.G. 2007. Mechanisms of eye development and evolution of the arthropod visual system: The lateral eyes of Myriapoda are not modified insect ommatidia. Organisms Diversity \& Evolution 7, 20-32. DOI 10.1016/j.ode.2006.02.004

HaUg, J.T. \& HaUg, C. 2013. An unusual fossil larva, the ontogeny of nachelatan lobsters and the evolution of metamorphosis. Bulletin of Geosciences 88(1), 195-206.

DOI 10.3140/bull.geosci.1374

Haug, J.T., MaAs, A., Haug, C. \& Waloszek, D. 2010b (accepted). Evolution of Crustacean Appendages. In WATLING, L. \& ThiEL, M. (eds) Functional Morphology and Diversity of Crustaceans.

Haug, J.T., MaAs, A. \& Waloszek, D. 2009. Ontogeny of two Cambrian stem crustaceans, †Goticaris longispinosa and $\uparrow$ Cambropachycope clarksoni. Palaeontographica A 289, $1-43$.

Haug, J.T., Waloszek, D., Haug, C. \& MaAs, A. 2010a. Highlevel phylogenetic analysis using developmental sequences: the Cambrian $\dagger$ Martinssonia elongata, $\dagger$ Musacaris gerdgeyeri gen. et sp. nov. and their position in early crustacean evolution. Arthropod Structure \& Development 39, 154-173. DOI 10.1016/j.asd.2010.01.005

Horridge, G.A. 1977. Insects which turn and look. Endeavour 1, 7-17. DOI 10.1016/0160-9327(77)90004-7

Horridge, G.A., Giddings, C. \& Stange, G. 1972. The superposition eye of skipper butterflies. Proceedings of the Royal Society London B 182, 457-495. DOI 10.1098/rspb.1972.0088

Keskinen, E., Takaku, Y., Meyer-Rochow, V.B. \& Hariyama, T. 2002. Microanatomical charackteristics of marginal ommatidia in three different size-classes of the semi-terrestrial isopod Ligia exotica (Crustacea; Isopoda). Biocell 26(3), 357-367.

LAND, M.F. 1981. Optics and vision in invertebrates, 471-592. In Autrum, H. (ed.) Vision in invertebrates. Handbook of sensory physiology, vol. VII/6B. Springer Verlag, Berlin.

Land, M.F. 1984. Crustacea, 699-725. In Ali, M.A. (ed.) Photoreception and vision in invertebrates. Plenum Publishing Corporation, New York.
Land, M.F. \& Nilsson, D.E. 2012. Animal eyes. 221 pp. Oxford University Press, Oxford.

DOI 10.1093/acprof:oso/9780199581139.001.0001

LAU, S.T.F. \& MEYER-Rochow, V.B. 2007. The compound eye of Orgyia antiqua (Lepidoptera: Lymantridae): Sexual dimorphism and light/dark adaptational changes. European Journal of Entomology 104, 247-258. DOI 10.14411/eje.2007.039

Lee, M.S.Y., Jago, J.B., Garcia-Bellido, D.C., Edgecombe, G.D., Gehling, J.G. \& PAterson, J.R. 2011. Modern optics in exceptionally preserved eyes of early Cambrian arthropods from Australia. Nature 474, 631-634.

DOI 10.1038/nature10097

LindSTRÖM, M. \& Nilsson, H.L. 1983. Spectral and visual sensitivities of Cirolana borealis Liljeborg, a deep-water isopod (Crustacea; Flabellifera). Journal of Experimental Marine Biology and Ecology 69, 243-256. DOI 10.1016/0022-0981(83)90072-2

Lindström, M., Fortelius, W. \& Meyer-Rochow, V.B. 1991. Expoure to bright light has little effect on eye sensitivity and ultrastructure of Saduria entomon (Crustacea; Isopoda; Valvifera). Zoological Science 8, 653-663.

LinNAEUs, C. 1758. Systema naturae per regna tria naturae, secundum classes, ordines, genera, species, cum characteribus, differentiis, synonymis, locis. Editio decima, reformata. ii +824 pp. Laurentii Salvii, Holmiae.

Maas, A., Braun, A., Dong, X.P., Donoghue, P., Müller, K.J., Olempska, E., Repetsk, J.E., Siveter, D.J., Stein, M. \& WaloszeK, D. 2006. The 'Orsten' more than a Cambrian Konservat-Lagerstätte yielding exceptional preservation. Palaeoworld 15, 266-282. DOI 10.1016/j.palwor.2006.10.005

Maas, A., Waloszek, D., Chen, J.-Y., Braun, A., Wang, X.-Q. \& Huang, D.-Y. 2004. Research on Early Phylogeny of Arthropoda. Progress in Natural Science 14(2), 158-166.

MaAs, A., Waloszek, D. \& Müller, K.J. 2003. Morphology, ontogeny and phylogeny of the Phosphatocopina (Crustacea) from the Upper Cambrian 'Orsten' of Sweden. Fossils and Strata 49, 1-238. DOI 10.1080/10020070412331343301

Mayrat, A. 1981. Nouvelle définition des yeux simples et composés chez les Arthropodes. Le cas des Amphipodes et des Cumacés. Archives de Zoologie Expérimentale et Générale 122, 225-236.

McCormick, T. \& Fortey, R.A. 1998. Independent testing of a paleobiological hypothesis: the optical design of two Ordovician pelagic trilobites reveals their relative paleobathymetry. Paleobiology 24(2), 235-253.

Meggitt, S. \& Meyer-Rochow, V.B. 1975. Two calculations on optically non-homogeneous lenses, 314-320. In HoRRIDGE, G.A. (ed.) The compound eye and vision in insects. Clarendon Press, Oxford.

MENZI, U. 1987. Visual adaptation in diurnal and nocturnal ants. Journal of Comparative Physiology A 160, 11-21.

DOI 10.1007/BF00613437

MeYer-Rochow, V.B. 1975. Larval and adult eye of the Western rock lobster Panulirus longipes. Cell and Tissue Research 162, 439-457. DOI 10.1007/BF00209345

Meyer-Rochow, V.B. 1981. The eye of Orchomene sp. cf. $O$. rossi, an amphipod living under the Ross Ice Shelf (Antarctica). Proceedings of the Royal Society of London, Biological Sciences 212, 93-111. 
Meyer-Rochow, V.B. 1982. The divided eye of the isopod Glyptonotus antarcticus: effects of unilateral dark adaptation and temperature elevation. Proceedings of the Royal Society of London, Biological Sciences 215, 433-450.

MEYeR-Rochow, V.B. 1985. A study of unusual intracellular organelles and ultrastructural organization of the eye of Gammarus oceanicus fixed in the midnight sun of the Spitzbergen (Svålbard) summer. Biomedical Journal 6, 353-367.

MeYer-Rochow, V.B. 2001. The crustacean eye: dark/light adaptation, polarization sensitiovity, flicker fusion frequency, and photoreceptor damage. Zoological Science 18, 1175-1197. DOI 10.2108/zsj.18.1175

Meyer-Rochow, V.B. \& Juberthie-Jupeau, L. 1983. An open rhabdom in a decapod photoreceptor: structure and possible function of the eye of Typhlatya. Biologie Cellulaire 49, $278-282$.

MeYer-Rochow, V.B. \& LaU, S.T.F. 2008. Sexual dimorphism in the compound eye of the moth Operophthera brumata (Lepidoptera, Geometridae). Invertebrate Biology 127, 201-216. DOI 10.1111/j.1744-7410.2008.00131.x

MeYer-Rochow, V.B. \& LaughLin, S.B. 1997. Intracellulart recordings from photoreceptors of the Antarctic isopod Glyptonotus antarcticus. $33^{\text {rd }}$ International Congress of the Physiological Sciences, St. Petersburg, P-071.01.

Meyer-Rochow, V.B. \& Nilsson, H.L. 1999. Compound eyes in polar regions, caves, and the deep sea, 125-142. In EGUCHI, E. \& TominaGa, Y. (eds) Atlas of arthropod sensory receptors. Springer Verlag, Tokyo.

Meyer-Rochow, V.B., Stephan, H. \& Moro, S.D. 1991. Morphological and anatomical observations on the hairy eyes of males and females of the marine amphipod Dulichia porrecta (Crustacea; Amphipoda; Podoceridae). Bolletino di Zoologica 58, 59-69. DOI 10.1080/11250009109355729

Meyer-Rochow, V.B. \& Tiang, K.M. 1979. The effects of light and temperature on the structural organization of the eye of the Antarctic amphipod Orchomene plebs (Crustacea). Proceedings of the Royal Society of London, Biological Sciences 206, 353-368.

Mishra, M., Jeffs, A. \& Meyer-Rochow, V.B. 2006. Eye structure of the phyllosoma larva of the rock lobster Jasus edwardsii (Hutton, 1875): How does it differ from that of the adult? Invertebrate Reproduction and Development 49, 213-222. DOI 10.1080/07924259.2006.9652209

Müller, C.H.G., Rosenberg, J., Richter, S. \& Meyer-Rochow, V.B. 2003. The compound eye of Scutigera coleoptrata (Linnaeus, 1758) (Chilopoda: Notostigmophora): an ultrastructural reinvestigation that adds support to the Mandibulata concept. Zoomorphology 122, 191-209.

DOI 10.1007/s00435-003-0085-0

Müller, C.H.G., Sombke, A. \& Rosenberg, J. 2007. The fine structure of the eyes of some bristly millipedes (Penicillata, Diplopoda): Additional support for the homology of mandibulate ommatidia. Arthropod Structure \& Development 36, 463-476. DOI 10.1016/j.asd.2007.09.002

MÜLLER, K.J. 1979a. Body appendages of paleozoic Ostracodes. Proceedings of the VII International Symposium on Ostracodes. Taxonomy, Biostratigraphy and Distribution of Ostracodes, 5-7.

MüLLER, K.J. 1979b. Ostracoden mit erhaltenen Gliedmaßen aus einem oberkambrischen Stinkkalk-Geschiebe. Der Geschiebesammler 13(2), 91-94.

MüLLER, K.J. 1983. Crustacea with preserved soft parts from the Upper Cambrian of Sweden. Lethaia 16, 93-109. DOI 10.1111/j.1502-3931.1983.tb01704.x

MüLLER, K.J. 1985. Exceptional preservation in calcareous nodules. Philosophical Transactions of the Royal Society of London B 311, 67-73. DOI 10.1098/rstb.1985.0139

MüLLER, K.J. \& WALoszeK, D. 1985. A remarkable arthropod fauna from the Upper Cambrian 'Orsten' of Sweden. Transactions of the Royal Society of Edinburgh, Earth Sciences 76, 161-172. DOI 10.1017/S0263593300010427

MüLLER, K.J. \& WALOSSEK, D. 1987. Morphology, ontogeny, and life-habit of Agnostus pisiformis (Linnaeus, 1757) from the Upper Cambrian of Sweden. Fossils and Strata 19, 1-124.

MülleR, K.J. \& WaloszeK, D. 1991. Ein Blick durch das $<$ Orsten>-Fenster in die Arthropodenwelt vor 500 Millionen Jahren. Verhandlungen der Deutschen Zoologischen Gesellschaft 84, 281-294.

Nagashima, T. \& Meyer-Rochow, V.B. 1995. Ommatidial structure of adult stonefly, Oyama lugubris (McLachlan) (Plecoptera: Perlidae). Japanese Journal of Entomology 63, 503-514.

Nemanic, P. 1975. Fine structure of the compound eye of Poreclllio scaber in light and dark adaptation. Tissue and Cell 7, 453-468. DOI 10.1016/0040-8166(75)90018-X

NiLSSON, D.E. 1990. Three unexpected cases of refraction superposition eyes in crustaceans. Journal of comparative Physiology A 167, 71-78. DOI 10.1007/BF00192407

Ninomiya, N., Tominaga, Y. \& Kuwabara, M. 1969. The fine structure of the compound eye of the damselfly. Zeitschrift für Zellforschung 98, 17-32. DOI 10.1007/BF00344505

OAKLEY, T.H. 2003. On homology of arthropod compound eyes. Integrative and Comparative Biology 43, 522-530. DOI 10.1093/icb/43.4.522

Paterson, J.R., García-Bellido, D.C., Lee, M.S.Y., Brock, G.A., JAHO, J.B. \& EDGECOMBE, G.D. 2011. Acute vision in the giant Cambrian predator Anomalocaris and the origin of compound eyes. Nature 480, 237-240. DOI 10.1038/nature10689

Paulus, H.F. 1979. Eye structure and the morphology of the arthropoda, 299-383. In GuPTA, A.P. (ed.) Arthropod Phylogeny. Van Norstrand Reinhold Co., New York \& London.

Peng, S., Babcock, L., Robison, R., Lin, H.L., Rees, M. \& Saltzmann, M. 2004. Global Standard stratotype-section and point (GSSP) of the Furongian series and Paibian stage (Cambrian). Lethaia 37, 365-379.

DOI 10.1080/00241160410002081

RichteR, S. 2002. The tetraconata concept: hexapod-crustacean relationships and the phylogeny of crustacea. Organisnms, Diversity and Evolution 2, 217-237. DOI 10.1078/1439-6092-00048

Richter, S., Loesel, R., Purschke, G., Schmidt-Rhaesa, A., Scholtz, G., Stach, T., Vogt, L., Wanninger, A., Brenneis, G., Döring, C., Faller, S., Fritsch, M., Grobe, P., Heuer, C.M., Kaul, S., Møller, O.S., Müller, C.H.G., Rieger, V., Rothe, B.H., Stegner, M.E.J. \& Harzsch, S. 2010. Invertebrate neurophylogeny: suggested terms and definitions for a neuroanatomical glossary. Frontiers in Zoology 2010, 7-29. 
Rosenberg, J. \& Langer, H. 1995. Ultrastructure of the compound eyes of Pontoporeia affinis (Crustacea, Amphipoda) and effects of light on their fine structure. Zoology-Analysis of Complex Systems 99, 138-150.

Schoenemann, B. 2005. The Cambrian sight of view - suggestions to investigate eyes of the Chengjiang Fauna by comparison with recent visual systems. Acta Micropalaeontologica Sinica 22, 169-170.

Schoenemann, B. 2006. Cambrian View. Palaeoworld 15, 307-314. DOI 10.1016/j.palwor.2006.10.012

Schoenemann, B. 2007. Fossile Augensysteme: Bericht über zur Zeit durchgeführte Analysen fossiler Augensysteme. Freiberger Forschungshefte 15, 85-96.

Schoenemann, B., Castellani, C., Clarkson, E.N.K., Haug, J.T., MaAs, A., Haug, C. \& Waloszek, D. 2012. The sophisticated visual system of a tiny Cambrian crustacean: analysis of a stalked fossil compound eye. Proceedings of the Royal Society, London B 279, 1335-1340.

DOI 10.1098/rspb.2011.1888

Schoentmann, B. \& Clarkson, E.N.K. 2008. Analysis of fossilised eye systems and its relevance to palaeobiology. Entomologica Generalis 31(3), 287-299.

Schoentmann, B. \& Clarkson, E.N.K. 2010. Eyes and vision in the Chengjiang arthropod Isoxys indicating adaptation to habitat. Lethaia 44, 223-230. DOI 10.1111/j.1502-3931.2010.00239.x

Schoenemann, B. \& Clarkson, E.N.K. 2011a. At First Sight Functional analysis of Lower Cambrian eye systems. Palaeontographica A 297, 123-149.

Schoenemann, B. \& Clarkson, E.N.K. 2011b. The eyes of Leanchoilia. Lethaia 45, 524-531. DOI 10.1111/j.1502-3931.2012.00313.x

Schoentmann, B. \& Clarkson, E.N.K. 2013. Discovery of some 400 million year-old sensory structures in the compound eyes of trilobites. Scientific Reports, http://www.nature.com/srep/ 2013/130314/srep01429/full/srep01429.html

Schoenemann, B., Clarkson, E.N.K., Ahlberg, P. \& Dies Alvarez, M.E. 2010. A tiny eye indicating a planctonic trilobite. Palaeontology 53, 695-701.

DOI 10.1111/j.1475-4983.2010.00966.x

Schoenemann, B., Liu, J.N., Shu, D.G., Han, J.A. \& Zhang, Z.F. 2009. A Miniscule optimized visual system in the Lower Cambrian. Lethaia 42, 265-273.

DOI 10.1111/j.1502-3931.2008.00138.x

SNYDER, A.W. 1977. The acuity of compound eyes: physical limitations and design. Journal of Comparative Physiology 116, 161-182. DOI 10.1007/BF00605401

SNYDER, A.W. 1979. Physics of vision in compound eyes, 225-313. In Autrum, H. (ed.) Vision in invertebrates. Handbook of sensory physiology, vol. VII/6A. Springer-Verlag, Berlin.

Snyder, A.W., Stavenga, D.G. \& Laughlin, S.B. 1977. Spatial information capacity of compound eyes. Journal of Comparative Physiology 116, 183-207.

Stavenga, D.G. 1989. Pigments in compound eyes, 152-172. In
Stavenga, D.G. \& Hardie, R.C. (eds) Facets of vision. Springer Verlag, Berlin, Heidelberg, New York.

Terfelt, F., Eriksson, M.E., Ahlberg, P. \& BABcock, L. 2008. Furongian Series (Cambrian) biostratigraphy of Scandinavia a revision. Norwegian Journal of Geology 88, 73-87.

Tanaka, G., Parker, A.R., Siveter, D.J., Maeda, H. \& FuruTANI, M. 2009. An exceptionally well-preserved Eocene dolichopodid fly eye: function and evolutionary significance. Proceedings of the Royal Society of London, Biological Sciences 276, 1015-1019.

ThIELE, H. 1971. Über die Fazettenaugen von land- und wasserbewohnenden Crustaceen. Zeitschrift für Morphologie 69, 9-22. DOI 10.1007/BF00294386

Wachmann, E. 1970. Zum Feinbau der Ommatidien von Pteronemobius heydeni (Fisch.) (Orthoptera; Gryllidae). Zeitschrift fur Zellforschung 108, 46-58. DOI 10.1007/BF00335942

WALoszeK, D. 1995. The Upper Cambrian Rehbachiella, its larval development, morphology and significance for the phylogeny of Branchiopoda and Crustacea. Hydrobiologia 298, 1-13. DOI 10.1007/BF00033797

Walossek, D. 1993. The Upper Cambrian Rehbachiella kinnekullensis Müller, 1983, and the phylogeny of Branchiopoda and Crustacea. Fossils and Strata 32, 1-202.

Waloszek, D., Chen, J., MAAs, A. \& WAng, X. 2005. Early Cambrian arthropods - new insights into arthropod head and structural evolution. Arthropod Structure \& Development 34, 189-205. DOI 10.1016/j.asd.2005.01.005

Waloszek, D., MaAs, A., Chen, J.-Y. \& Stein, M. 2007. Evolution of cephalic feeding structures and the phylogeny of Arthropoda. Palaeogeography, Palaeoclimatology, Palaeoecology 254, 273-287. DOI 10.1016/j.palaeo.2007.03.027

WAloszeK, D. \& Müller, K.J. 1990. Stem-lineage crustaceans from the Upper Cambrian of Sweden and their bearing upon the position of Agnostus. Lethaia 23(4), 409-427. DOI 10.1111/j.1502-3931.1990.tb01373.x

WaloszeK, D. \& MülleR, K.J. 1998a. Cambrian 'Orsten'-type arthropods and the phylogeny of Crustacea, 139-153. In Fortey, R.A. \& Thomas, R. (eds) Arthropod relationships. Systematics Association Special Volume 55. Chapman \& Hall, London.

WaloszeK, D. \& Müller, K.J. 1998b. Early Arthropod Phylogeny in the Light of the Cambrian 'Orsten' fossils, 185-231. In Edgecombe, G. (ed.) Arthropod Fossils and Phylogeny. Columbia University Press.

WARRANT, E.J. 1999. Seeing better at night: life style, eye design and the optimum strategy of spatial and temporal summation. Vision Research 39, 1611-1630. DOI 10.1016/S0042-6989(98)00262-4

WARRANT, E. \& NiLSSON, D.-E. 2006. Invertebrate Vision. 547 pp. Cambridge University Press, Cambridge.

Wolken, J.J. \& GALLIK, G.J. 1965. The compound eye of a crustacean, Leptodora kindtii. Journal of Cell Biology 26, 968-973. DOI 10.1083/jcb.26.3.968

YAGI, N. \& KoYAMA, N. 1963. The compound eye of Lepidoptera. 319 pp. Maruzen Co., Tokyo. 